\title{
The epigenetic landscape of clear-cell renal cell carcinoma
}

\author{
Katarzyna Kluzek ${ }^{1}$, Hans A Bluyssen ${ }^{1}$, Joanna Wesoly² \\ ${ }^{1}$ Department of Human Molecular Genetics, ${ }^{2}$ Laboratory of High Throughput Technologies, Institute of \\ Molecular Biology and Biotechnology, Faculty of Biology, Adam Mickiewicz University in Poznan, \\ Umultowska 89, 61-614 Poznan, Poland.
}

\begin{abstract}
Clear cell renal cell carcinoma (ccRCC) is the most common subtype of all kidney tumors. During the last few years, epigenetics has emerged as an important mechanism in ccRCC pathogenesis. Recent reports, involving large-scale methylation and sequencing analyses, have identified genes frequently inactivated by promoter methylation and recurrent mutations in genes encoding chromatin regulatory proteins. Interestingly, three of detected genes (PBRM1, SETD2 and BAP1) are located on chromosome 3p, near the VHL gene, inactivated in over $80 \%$ ccRCC cases. This suggests that $3 p$ alterations are an essential part of ccRCC pathogenesis. Moreover, most of the proteins encoded by these genes cooperate in histone H3 modifications. The aim of this review is to summarize the latest discoveries shedding light on deregulation of chromatin machinery in ccRCC. Newly described ccRCCspecific epigenetic alterations could potentially serve as novel diagnostic and prognostic biomarkers and become an object of novel therapeutic strategies.
\end{abstract}

Received: 30 April 2015; Accepted after revision: 26 May 2015; Published: 28 May 2015

Author for correspondence: Joanna Wesoly $\mathrm{PhD}$, Laboratory of High Throughput Technologies, Institute of Molecular Biology and Biotechnology, Faculty of Biology, Adam Mickiewicz University in Poznan, Umultowska 89, 61-614 Poznan, Poland. E-mail: j.wesoly@amu.edu.pl

How to cite: Kluzek K, Bluyssen HA, Wesoly J. The epigenetic landscape of clear-cell renal cell carcinoma. Journal of Kidney Cancer and VHL 2015;2(3):90-104. Doi: http://dx.doi.org/10.15586/jkcvhl.2015.33

\section{Introduction}

Kidney cancer is one of the 15 most common malignancies occurring globally, with more than 270,000 new cases every year worldwide (1-3). The majority of malignant kidney tumors are renal cell carcinomas (RCC) with the most common and aggressive subtype being clear-cell renal cell carcinoma (ccRCC), comprising approximately $70 \%$ of all kidney tumors (4). Localized ccRCC is potentially curable by resection, though about $30 \%$ of patients relapse after initial nephrectomy (5). Unfortunately, ccRCC is frequently non- symptomatic in the early phases, and is repeatedly detected in advanced stage often with metastases (6). When metastasized, ccRCC is chemo- and radiation-resistant and in most cases remains incurable, resulting in a $95 \%$ mortality rate $(7,8)$.

To date no effective ccRCC treatment has been developed and none of the potential biomarkers have been approved for clinical application. For many years von HippelLindau (VHL) tumor suppressor gene (TSG) was the only TSG associated with ccRCC pathogenesis (9). Attempts to detect other mutated genes have been unsuccessful for 
a long time, though deregulation of chromatin machinery has recently emerged as an important mechanism in renal neoplasms. Large-scale sequencing projects have identified novel TSGs, mapped to the frequently lost 3p21 locus and functioning as epigenetic chromatin and/or histone modifiers, indicating epigenetic changes may play an important role in ccRCC development (10-12). Silencing of VHL through promoter methylation in ccRCC was one of the first examples of this phenomenon and so far approximately 60 genes have been suggested to be epigenetically deregulated in ccRCC (13). Here, we summarize the most recent discoveries in the field of ccRCC epigenomics, providing potential diagnostic and prognostic biomarkers as well as possible novel targets for therapeutic intervention.

\section{Epigenetic alterations in ccRCC}

The main mechanisms responsible for chromatin state regulation are: DNA methylation, nucleosome remodeling, and covalent histone modifications through methylation, acetylation, phosphorylation, ubiquitination, or sumoylation. These modifications can directly change DNA organization and/or accessibility as well as lead to the recruitment of proteins altering chromatin structure and in consequence influence transcription, replication, recombination and DNA repair $(14,15)$. Recent genome-wide methylation studies and sequencing projects demonstrated that the disruption of epigenetic control has a significant role in the initiation and progression of ccRCC (16-18).

\section{Inactivation of potential tumor suppressor genes through DNA methylation}

DNA methylation is the best studied epigenetic modification and the only epigenetic mark with a well described mechanism of mitotic inheritance (19). It plays an important role in various biological processes, for example, genomic imprinting, transposable elements silencing, and embryonic development (20). Methylation patterns are generated and maintained by DNA methyltransferases (DNMTs). DNMT1 acts during replication and maintains methylation of the new DNA strand, DNMT3a and DNMT3b are de novo methyltransferases that act independently of replication and display no preference for unmethylated nor hemi-methylated DNA (20-23).

The majority of $\mathrm{CpG}$-rich promoter regions (CpG islands) occupying near $60 \%$ of human gene promoters usually remain unmethylated (24). Gene silencing by promoter region methylation of TSGs is a frequent mechanism described in human cancers, with epigenetic inactivation of VHL in ccRCC being one of the first examples $(13,25,26)$. VHL, while mutated in approximately $80 \%$ of sporadic ccRCC, is inactivated by methylation in an additional $\sim 10 \%$ of cases $(27,28)$. Identification of other epigenetically inactivated TSGs was an important approach to study the pathogenesis of ccRCC, and promoter hypermethylation of several genes commonly inactivated in ccRCC has been documented (18). Based on a search of online databases, compilation of candidate genes reported in numerous studies to show tumor-specific hypermethylation in ccRCC, has been published in 2010 (28). Morris et al. described 38 genes methylated in ccRCC, among those only a small number was methylated with high frequency $(\geq 50 \%$ of cases: APAF 1 , COL $1 A 1$, DKK2, DKK3, SFRP2, SFRP4, SFRP5, and WIF 1$)$ while rarely $(<10 \%)$ in matched normal tissue (28).

The earlier, initial studies mostly implemented targeted, candidate-driven analyses. Recently, several whole genome strategies also have been applied. A large functional epigenetic screen of gene upregulation post 5-aza-2'-deoxycytidine demethylation treatment by high-density gene expression microarrays in $11 \mathrm{RCC}$ cell lines (KTCL 26, RCC4, UMRC2, UMRC3, SKRC18, SKRC39, SKRC45, SKRC47, SKRC54, 786-0 and Caki-1) was applied by Morris et al. Genes re-expressed after demethylation were validated in 61 primary tumors ( 80\% clear cell and 20\% non-clear cell RCC). Five genes (BNC1, COL14A1, CST6, PDLIM4, and SFRP1) demonstrated frequent tumor-specific promoter region methylation (>30\%), associated with transcriptional silencing. Re-expression of BNC1, CST6, and SFRP1 suppressed the 
growth of RCC cell lines, whereas RNAi knock-down of BNC1, SFRP1, and COL14A1 increased their growth, suggesting tumor suppressor activity (29). Similarly, methylated DNA immunoprecipitation (MeDIP) of primary tumors, followed by high-density wholegenome expression microarray comparative analysis revealed 9 genes frequently methylated in primary ccRCC tumour samples: PCDH8 (58\%), KLHL35 (39\%), ATP5G2 (36\%), CCDC8 (35\%), FBN2 (34\%), ZSCAN18 (32\%), their promoter hypermethylation resulting in gene silencing (30). None of these genes have been reported previously to be methylated in RCC nor other cancers.

Genome-wide DNA methylation studies in ccRCC have also been performed using BeadChip arrays. Comparison of DNA methylation profiles in familial $(\mathrm{n}=29)$ and sporadic $(\mathrm{n}=20) \mathrm{VHL}^{+/+}$ccRCC showed more frequently methylated RASSF1, PITX2, CDH13, HS3ST2, TWIST1, TAL1, TUSC3, and DCC loci in sporadic cases, indicating differences in tumorigenesis mechanisms dependent on VHL status (31). Several novel ccRCC TSG candidates (SLC34A2, OVOL1, DLEC1, TMPRSS2, SSTand BMP4) have been found in a global study of CpG methylation in $38 \mathrm{ccRCC}$ and 9 age-matched healthy tissues $(\sim 27,500$ CpGs and $>14,000$ genes) (32). All of those exhibited frequent transcriptional silencing associated with promoter methylation (20$60 \%$ of cases).

Dmitriev et al. focused on genetic and epigenetic destabilization of genes on chromosome 3 (33). The study (validated by bisulfite genomic sequencing) showed 22 genes displaying high frequency of methylation (17-57\%) and/or deletion in ccRCC. Identified genes included wellknown TSGs VHL, CTDSPL, LRRC3B, ALDH1L1, and EPHB1, but also genes not previously linked to cancer development (LRRN1, GORASP1, FGD5, and PLCL2). Proteins encoded by a part of these genes are involved in signaling pathways and biological processes frequently affected in cancer, like apoptosis (GORASP1), regulation of actin cytoskeleton (FGD5), transmembrane signaling systems (GNAI2) or regulation of NFkappaB activity
(NKIRAS1). Dmitriev et al. further confirm that mechanism of ccRCC development is linked to destabilization of genes at chromosome 3 , discussed in more detail in the next paragraph.

Studies described above have identified a large number of genes methylated in sporadic ccRCC. There is small overlap between studies and consensus on which genes play a role in its etiology and whether any of those are of relevance clinically. However, all of the reported genes are involved in processes often deregulated during tumorigenesis: apoptosis, proliferation, cell survival and tumor invasion. The Cancer Genome Axis (TCGA) Kidney Renal Clear Cell Carcinoma (KIRC) database provides an excellent opportunity to confirm and unify previously obtained results (16). These data include 199 ccRCC tumor/normal paired analyses using the Infinium HumanMethylation27 BeadChip validated on 160 ccRCC tumor/normal paired samples using the Infinium HumanMethylation450 BeadChip.

Mutations of genes regulating epigenetic modifications

Non-covalent mechanisms, such as nucleosome remodeling can change chromatin structure and influence gene activity by altering the accessibility of regulatory DNA sequences to transcription factors (34). Currently, there are four known families of ATP-dependent remodeling complexes, characterized by different core ATPases: SWI/SNF, ISWI, NURD/Mi-2/CHD and INO80. Mutations of SWI/SNF subunits were documented in approximately $20 \%$ of human cancers (for example, medulloblastoma, breast cancer), indicating that inactivation of this complex is important in tumor formation (35). PBRM1 encodes the chromatin targeting subunit (BAF180) of the ATP-dependent SWI/SNF chromatin remodeling complex, implicated in proliferation, replication, transcription and DNA repair (Figure 1) (36). Truncating mutations in PBRM 1 have been found in 88/257 (34\%) of ccRCC cases (10). Further studies have shown similar mutation frequencies, making it the second most commonly altered gene in ccRCC, next to VHL (37). However, there is 


\section{B. Gene inactivation by mutation}

A. Gene inactivation by DNA methylation

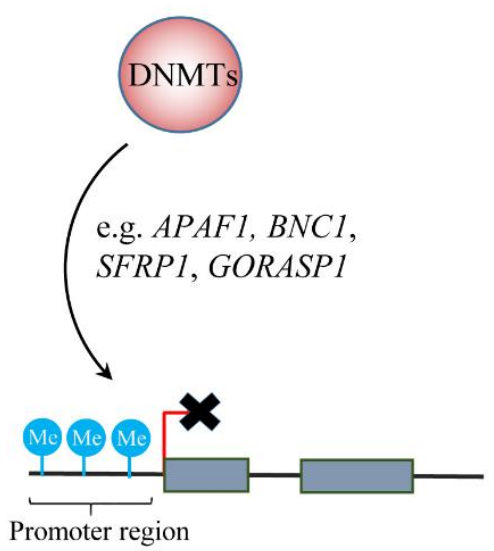

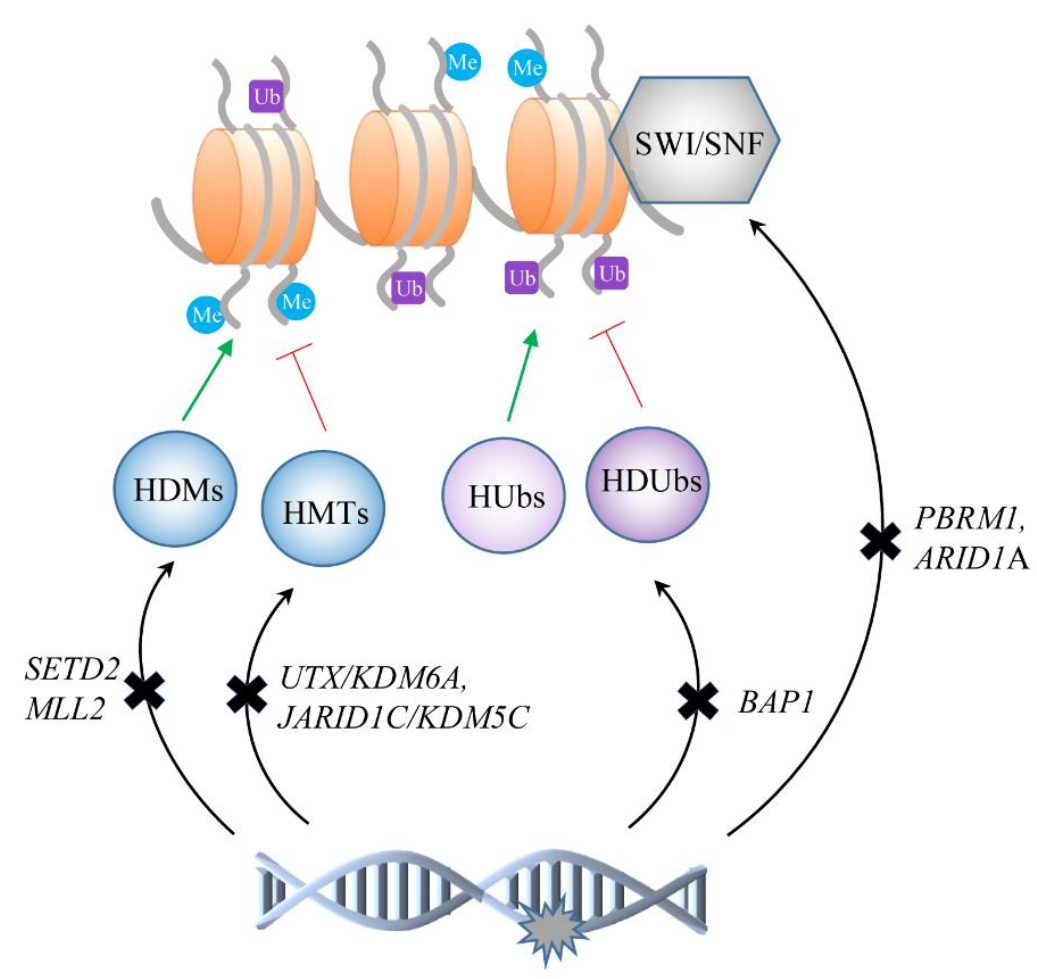

Figure 1. Schematic representation of epigenetic changes identified in ccRCC tumors. DNMTs - DNA methyltransferases; HDMs - histone demethylases; HMTs - histone methyltransferases; Hubs histone ubiquitinases; HDUbs - histone deubiquitinases; SWI/SNF - chromatin remodeling complex.

no significant correlation between lack of PBRM1 expression and VHL mutations, and PBRM1 mutations occur at similar rates in tumors with or without VHL mutations (38). Functional in vitro assays in ccRCC cell lines with PBRM1 silenced via siRNA resulted in a significant increase of proliferation in $\mathrm{ACHN}$ and $786-\mathrm{O}$ cell lines (with wild type PBRM1) but not in A704 with a homozygous PBRM1 truncating mutation (10). In turn, reintroduction of PBRM1 into cells induced the cyclin-dependent kinase inhibitor p21 expression and led to reduction in cell proliferation (39). PBRM1 silencing results also in increased colony formation in soft agar and increases cell migration in 786-O, SN12C and TK10 cells, suggesting a tumor suppressive role for PBRM1 in ccRCC (10). Additionally, ccRCCs deficient in PBRM1 are associated with a distinct geneexpression signature enriched for genes implicated in the cytoskeleton and cell motility (40). However, how loss of PBRM1 function affects chromatin modulation patterns and promotes tumorigenesis is unknown.

In a small proportion of ccRCCs, ARID1A (1p35) encoding for different subunit of the SWI/SNF complex (BAF250A) was also found to be mutated (Figure 1) (10). In another study, in $16 \%$ patients with ccRCC, ARID1A copy number loss was detected - $67 \%$ of tumors $(n=79)$ had significantly lower expression of BAF250A than control tissue, and in approximately $70 \% \quad(\mathrm{n}=404)$ decreased ARID1A mRNA expression was found $(41,42)$. ARID1A mutations are present at high frequency in other cancers, for example, ovarian clear cell carcinomas (50\%), ovarian endometrioid carcinomas (30\%), and gastric cancers (29\%), and studies have suggested its roles in proliferation, differentiation, and apoptosis (43). The 
mechanism of ARID1A alterations and their role in ccRCC pathogenesis is still unclear.

Besides chromatin remodeling, histone modifications, controlled by balanced activity of histone modifying enzymes, also play a critical role in maintaining the proper functioning of cells (44). Most common N-terminal tail modifications include acetylation and methylation of lysine or arginine and serine phosphorylation (45). Depending on their type and location, modifications may influence the accessibility of chromatin or can recruit and/or block non-histone effector proteins. Various enzymes are responsible for this dynamic regulation, for example, histone acetyltransferases (HATs) and methyltransferases (HMTs) that add acetyl and methyl groups, respectively, as well as enzymes removing these groups: histone deacethylases (HDACs) and demethylases (HDMs) (46). Altered expression of some of those have been discovered in ccRCC, including SETD2 and MLL2 (methyltransferases) as well as JARID1C/KDM5C and UTX/KDM6A (demethylases) (Figure 1).

SETD2 (SET domain containing protein 2) is mutated in approximately $3 \%$ to $8 \%$ of ccRCC and its inactivation leads to loss or decrease of trimethylation of lysine 36 of histone H3 (H3K36me3) (10, 11, 47). In addition, a connection has been reported between SETD2 mutations and extensive DNA hypomethylation in ccRCC (16). Similar to VHL and PBRM1, SETD2 is located on chromosome $3 p$ and it was proposed as a novel TSG in ccRCC. A metaanalysis based on 5 different studies suggests SETD2 mutations cooperate with mutations in PBRM1 (48). In addition, Garlinger et al. have shown that distinct SETD2 mutations are present in the same tumor, suggesting a high selective pressure to mutate SETD2 (49). How its biallelic inactivation is connected to ccRCC remains unclear. Two studies have linked SETD2 and H3K36me3 to DNA mismatch repair and microsatellite instability of tumors $(50$, $51)$. This finding was not confirmed by Kanu et al., who suggest a role for SETD2 in nucleosome reassembly, suppression of replication stress, and the coordination of DNA double-strand breaks (DSBs) repair by homologous recombination (HR) (52).
Findings linking SETD2 to HR have been also reported by Carvalho et al., who showed it is required for ATM activation upon formation of DSBs, and for HR repair of DSBs by promoting the formation of RAD51 filaments. SETD2-mutant ccRCC cells displayed impaired DNA damage signaling, decreased cell survival after DNA damage and failure to activate the p53mediated checkpoint (53). Another methyltransferase frequently mutated in ccRCC, MLL2 (mixed-lineage leukemia protein 2, localized at 12q13.12), directs tri-methylation of histone H3 lysine 4 (11). The role of MLL2 in pathogenesis of ccRCC is currently unknown.

TSG function was also suggested for UTX/KDM6A gene coding for histone demethylase (with 3\% mutation frequency in ccRCC) (11, 54). UTX/KDM6A demethylates H3K27me3 linked with repressed chromatin. It associates with MLL2 which also interacts with another H3K4 demethylase JARID1C/KDM5C, found to be frequently deactivated in ccRCC. Loss of JARID1C in 786-O ccRCC cells (VHL -/) leads to significantly lower H3K4Me3 levels than in $\mathrm{VHL}^{+/+}$. JARID1C is proposed to have a tumor suppressor role - its knockdown in 786-O $\mathrm{VHL}^{-/-} \mathrm{ccRCC}$ cells significantly enhanced tumor growth in a mice xenograft model (55). Taken together, these data implicate deregulation of methylation/demethylation of histone H3 (a major regulator of euchromatin/transcription), as an important and complex phenomenon in ccRCC etiology.

The BRCA1 Associated Protein-1 (BAP1) gene is also often mutated in ccRCC (8$14 \%)(12,37,56)$. It is located at $3 p$ and codes for a nuclear deubiquitinase targeting $\mathrm{H} 2 \mathrm{~A}$, one of the most abundant ubiquitinated proteins in the nucleus, next to H2B (Figure 1) (57). BAP1 interacts with Host Cell Factor C1 (HCF-1), which recruits histone-modifying enzymes and serves as a scaffold for chromatin remodeling complexes, promoting the inhibition of cell proliferation (37). Interestingly, BAP1 and PBRM1 mutations are mutually exclusive and loss of either BAP1 or PBRM 1 proteins has been observed in approximately $70 \%$ of ccRCC cases $(37,56)$. Moreover, VHLdeficient mice with one active allele of BAP1 
exhibited features of human ccRCC, which suggests an important role of BAP1 in the pathogenesis of ccRCC (58).

\section{Chromatin organization and chromatin accessibility changes}

Formaldehyde-assisted isolation of regulatory elements (FAIRE), enables interrogation of chromatin accessibility changes and is based on isolation of nucleosome-depleted regions of DNA, harboring regulatory elements (active transcriptional start sites, transcriptional enhancers, and silencers). Studies using this method showed functional consequences of mutations in genes encoding chromatin regulatory proteins on chromatin organization and transcription in human tumors (59). Buck et al. performed FAIRE on matched pairs of tumor/healthy samples and identified decreased chromatin accessibility at genes previously associated with ccRCC, such as PBRM1, SETD2 and MLL2 (60). Arraybased methylation analysis on this same set of tumors revealed that chromatin remodeling can occur in parallel with methylation or independent of it. Recently, Simon et al. used FAIRE to define the chromatin landscape in a cohort of 42 primary ccRCC tumors and 7 matched normal tissues, and studied the possible association of variations in chromatin organization with mutations in SETD2 (61). Changes in chromatin accessibility were identified primarily within actively transcribed genes, and increase in chromatin accessibility was linked to alterations in RNA processing (for example, intron retention and aberrant splicing), affecting $\sim 25 \%$ of all expressed genes. Moreover, in tumors lacking H3K36me3 decreased nucleosome occupancy proximal to aberrantly spliced exons was observed. This study links mutations in SETD2 to chromatin accessibility changes and RNA processing defects.

\section{Epigenetic modifications as markers for ccRCC diagnosis, prognosis, and surveillance}

No effective and noninvasive strategy for detection and prognosis of ccRCC has been established to date. ccRCC usually remains asymptomatic until a relatively late stage, therefore early detection, accurate prediction of disease progression and monitoring are critical. Potentially, altered expression of recently reported histone modifiers, might be of clinical relevance (Table 1). ccRCC patients with BAP1 mutations were significantly more likely to present with advanced clinical stage and metastases, and shorter overall survival $(56,62)$. Similarly, PBRM1 downregulation correlated with advanced tumor stage, low differentiation grade and worse patient outcome while SETD2 mutations correlated with a high relapse rate $(38,56)$. Moreover, tumors with expression changes of PBRM1 or BAP1, SETD2 and KDM5C were more likely to present with stage III disease or higher (62). Analysis of cancer specific survival (CSS) performed in a large patient cohort of 188 patients and additionally 421 from TCGA, partially confirmed these initial findings (63). BAP1 mutations were associated with worse CSS in both cohorts (MSKCC, $p=0.002$; TCGA, $p=0.002$ ) while SETD2 only in the TCGA cohort $(p=0.036)$. PBRM1 mutations were not correlated with CSS in this study.

Cancer cells display global alterations of DNA methylation, therefore methylation profiling may be implemented in ccRCC biomarker discovery. A specific cancer phenotype designated as the $\mathrm{CpG}$ island methylator phenotype (CIMP) was found in ccRCC. It is characterized by DNA hypermethylation of 17 marker genes and by more aggressive tumors, poorer patient outcome, and a higher probability of both, recurrence and disease-related death. ccRCC-CIMP was validated and could be useful for diagnosis and prognostication of the patients $(64,65)$. A vast amount of aberrantly methylated genes, described in previous paragraphs and exemplified in Table 1, may potentially serve as biomarkers $(4,18,66,67)$. However, to predict methylation specificity/sensitivity and thus diagnostic potential, these data require more detailed investigation.

Most studies on both mutation status of histone modifiers and gene methylation were conducted on tissue samples. Fluid based biomarkers for detection, staging and progression monitoring would be more attractive due to easy, non-invasive 
Table 1. Genes involved in epigenetic DNA and chromatin modifications, proposed as potential biomarkers in ccRCC (a genes with methylation frequency above $30 \%$ ).

\begin{tabular}{|c|c|c|c|c|c|c|c|c|c|}
\hline & \multicolumn{2}{|c|}{ Gene function } & $\begin{array}{l}\text { Gene } \\
\text { name }\end{array}$ & Locus & $\begin{array}{l}\text { Methylation } \\
\text { mutation } \\
\text { frequency }\end{array}$ & \multicolumn{2}{|l|}{$\begin{array}{l}\text { Type of } \\
\text { sample }\end{array}$} & $\begin{array}{c}\text { Type of } \\
\text { potential } \\
\text { biomarker }\end{array}$ & Ref. \\
\hline \multirow{18}{*}{ 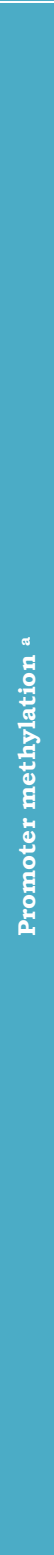 } & \multirow{8}{*}{ 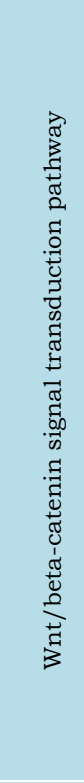 } & \multirow{3}{*}{ 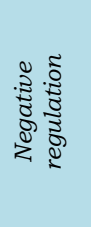 } & DKK1 & $10 \mathrm{q} 11$ & $52 \%$ & $\begin{array}{l}\text { tumor } \\
(\mathrm{n}=50)\end{array}$ & $\begin{array}{l}\text { methylation frequency higher } \\
\text { in advanced tumor stage }\end{array}$ & prognostic & (89) \\
\hline & & & DKK2 & $4 q 25$ & $58 \%$ & $\begin{array}{l}\text { tumor } \\
(\mathrm{n}=52)\end{array}$ & $\begin{array}{l}\text { methylation frequency higher } \\
\text { in high grade, stage, and size } \\
\text { tumors }\end{array}$ & prognostic & (90) \\
\hline & & & DKK3 & $11 \mathrm{p} 15$ & $50 \%$ & $\begin{array}{l}\text { tumor } \\
(\mathrm{n}=62)\end{array}$ & $\begin{array}{l}\text { cancer cell specific } \\
\text { methylation }\end{array}$ & predictive & (91) \\
\hline & & \multirow{5}{*}{ 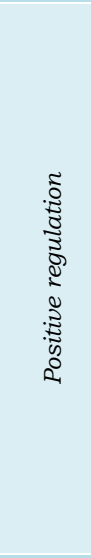 } & SFRP1 & $8 \mathrm{p} 11$ & $34 \%$ & $\begin{array}{l}\text { tumor } \\
(\mathrm{n}=61)\end{array}$ & $\begin{array}{l}\text { methylation associated with } \\
\text { poor prognosis }\end{array}$ & prognostic & (27) \\
\hline & & & SFRP2 & $4 q 31$ & $53 \%$ & $\begin{array}{l}\text { tumor } \\
(n=62)\end{array}$ & $\begin{array}{l}\text { cancer cell specific } \\
\text { methylation } \\
\text { methylation frequency higher } \\
\text { in high grade and stage } \\
\text { tumors }\end{array}$ & $\begin{array}{l}\text { predictive } \\
\text { prognostic }\end{array}$ & (91) \\
\hline & & & SFRP4 & $7 \mathrm{p} 14-13$ & $53 \%$ & $\begin{array}{l}\text { tumor } \\
(\mathrm{n}=62)\end{array}$ & $\begin{array}{l}\text { cancer cell specific } \\
\text { methylation }\end{array}$ & $\begin{array}{l}\text { predictive } \\
\text { prognostic }\end{array}$ & (91) \\
\hline & & & SFRP5 & $10 q 24$ & $45 \%$ & $\begin{array}{l}\text { tumor } \\
(\mathrm{n}=62) \\
\text { serum } \\
(\mathrm{n}=33)\end{array}$ & $\begin{array}{l}\text { cancer cell specific } \\
\text { methylation } \\
\text { methylation frequency higher } \\
\text { in high grade and stage } \\
\text { tumors }\end{array}$ & $\begin{array}{l}\text { predictive } \\
\text { prognostic }\end{array}$ & (91) \\
\hline & & & WIF 1 & $12 q 14$ & $73 \%$ & $\begin{array}{l}\text { tumor } \\
(\mathrm{n}=62)\end{array}$ & $\begin{array}{l}\text { cancer cell specific } \\
\text { methylation }\end{array}$ & predictive & (91) \\
\hline & \multirow{3}{*}{ 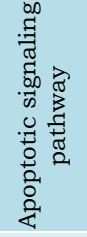 } & \multirow{3}{*}{$\begin{array}{l}0 \\
0 \\
0 \\
0 \\
0 \\
0 \\
0 \\
0 \\
0 \\
0\end{array}$} & $A P A F-1$ & $12 q 23$ & $\begin{array}{l}41 \% \\
41 \%\end{array}$ & $\begin{array}{l}\text { tumor } \\
(\mathrm{n}=90) \\
\text { tumor } \\
(\mathrm{n}=196)\end{array}$ & $\begin{array}{l}\text { methylation associated with } \\
\text { low overall survival } \\
\text { risk of metastatic disease, } \\
\text { cancer-related death }\end{array}$ & $\begin{array}{l}\text { prognostic } \\
\text { prognostic }\end{array}$ & $\begin{array}{l}\text { (92) } \\
\text { (93) }\end{array}$ \\
\hline & & & DAPK-1 & $9 q 21$ & $64 \%$ & $\begin{array}{l}\text { tumor } \\
(n=196)\end{array}$ & $\begin{array}{l}\text { frequently methylated in high } \\
\text { stage tumors }\end{array}$ & prognostic & (93) \\
\hline & & & KILLIN & $10 q 23$ & $95 \%$ & $\begin{array}{l}\text { tumor } \\
(n=20)\end{array}$ & $\begin{array}{l}\text { cancer cell specific } \\
\text { methylation }\end{array}$ & diagnostic & (68) \\
\hline & \multirow{3}{*}{\multicolumn{2}{|c|}{$\begin{array}{l}\text { Extracellular } \\
\text { matrix } \\
\text { structural } \\
\text { constituent }\end{array}$}} & COL1A1 & 17q21 & $65 \%$ & $\begin{array}{l}\text { tumor } \\
(\mathrm{n}=20)\end{array}$ & $\begin{array}{l}\text { frequently methylated in } \\
\text { early-stage tumors }\end{array}$ & prognostic & (94) \\
\hline & & & COL14A1 & $8 q 23$ & $44 \%$ & $\begin{array}{l}\text { tumor } \\
(n=41)\end{array}$ & $\begin{array}{l}\text { poor prognosis independent } \\
\text { of tumor size, stage or grade }\end{array}$ & prognostic & (27) \\
\hline & & & FBN2 & $5 q 23$ & $\begin{array}{l}40 \% \\
52 \%\end{array}$ & $\begin{array}{l}\text { tumor } \\
(n=199) \\
(n=160)\end{array}$ & $\begin{array}{l}\text { cancer cell specific } \\
\text { methylation }\end{array}$ & predictive & (95) \\
\hline & \multirow{2}{*}{\multicolumn{2}{|c|}{$\begin{array}{l}\text { Regulation of } \\
\text { transcription }\end{array}$}} & BNC1 & $15 q 25$ & $46 \%$ & $\begin{array}{l}\text { tumor } \\
(\mathrm{n}=61)\end{array}$ & $\begin{array}{l}\text { poor prognosis independent } \\
\text { of tumor size, stage or grade }\end{array}$ & prognostic & (27) \\
\hline & & & HOXA5 & $7 \mathrm{p} 15$ & $51 \%$ & $\begin{array}{l}\text { tumor } \\
(\mathrm{n}=62)\end{array}$ & $\begin{array}{l}\text { methylation frequency higher } \\
\text { in high Fuhrman grade } \\
\text { tumors }\end{array}$ & prognostic & (96) \\
\hline & \multicolumn{2}{|c|}{ TSG } & DLEC1 & $3 p 21$ & $31 \%$ & $\begin{array}{l}\text { tumor } \\
(\mathrm{n}=81)\end{array}$ & $\begin{array}{l}\text { methylation frequency higher } \\
\text { in more advanced stage } \\
\text { tumors }\end{array}$ & prognostic & (97) \\
\hline & \multicolumn{2}{|c|}{$\begin{array}{l}\text { Inhibitor of } \\
\text { TGF } \square \text { signaling }\end{array}$} & GREM1 & $15 q 12$ & $63 \%$ & $\begin{array}{l}\text { tumor } \\
(\mathrm{n}=147)\end{array}$ & $\begin{array}{l}\text { high methylation frequency } \\
\text { associated with increased } \\
\text { tumor size, grade and stage }\end{array}$ & prognostic & (98) \\
\hline : & \multicolumn{2}{|c|}{$\begin{array}{l}\text { SWI/SNF } \\
\text { chromatin } \\
\text { remodeling } \\
\text { complex }\end{array}$} & PBRM1 & $3 p 21$ & $29 \%$ & $\begin{array}{l}\text { tumor } \\
(\mathrm{n}=185)\end{array}$ & $\begin{array}{l}\text { mutations associated with } \\
\text { advanced tumor stage }\end{array}$ & prognostic & (61) \\
\hline है & \multicolumn{2}{|c|}{$\begin{array}{l}\text { histone H3K4 } \\
\text { demethylation }\end{array}$} & $\begin{array}{l}\text { JARID1C/ } \\
\text { KDM5C }\end{array}$ & Xp11 & $8 \%$ & $\begin{array}{l}\text { tumor } \\
(\mathrm{n}=185)\end{array}$ & $\begin{array}{l}\text { mutations associated with } \\
\text { advanced tumor stage }\end{array}$ & prognostic & (61) \\
\hline : & \multicolumn{2}{|c|}{$\begin{array}{l}\text { histone H3К36 } \\
\text { trimethylation }\end{array}$} & SETD2 & $3 p 21$ & $\begin{array}{l}8 \% \\
11 \% \\
11 \%\end{array}$ & $\begin{array}{l}\text { tumor } \\
(n=185) \\
(n=421) \\
(n=106)\end{array}$ & $\begin{array}{l}\text { mutations associated with } \\
\text { worse cancer-specific survival } \\
\text { high relapse rate }\end{array}$ & $\begin{array}{l}\text { prognostic } \\
\text { prognostic } \\
\text { prognostic }\end{array}$ & $\begin{array}{l}(61) \\
(62) \\
(55)\end{array}$ \\
\hline 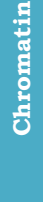 & \multicolumn{2}{|c|}{$\begin{array}{c}\text { catalytic } \\
\text { subunit of the } \\
\text { histone H2A } \\
\text { deubiquitinase }\end{array}$} & BAP1 & $3 p 21$ & $\begin{array}{c}6 \% \\
6 \% \\
10 \%\end{array}$ & $\begin{array}{l}\text { tumor } \\
(n=132) \\
(n=185) \\
(n=188) \\
(n=421)\end{array}$ & $\begin{array}{l}\text { mutations associated with } \\
\text { metastases and advanced } \\
\text { tumor stage } \\
\text { higher stage \& grade tumors; } \\
\text { shorter overall survival } \\
\text { worse cancer-specific survival }\end{array}$ & $\begin{array}{l}\text { prognostic } \\
\text { prognostic }\end{array}$ & $\begin{array}{l}(61) \\
(62)\end{array}$ \\
\hline
\end{tabular}


acquisition. Nevertheless, to date only a limited number of studies aimed at finding specific ccRCC biomarkers in blood or urine has been executed. Methylationbased biomarker candidates found in urine and serum of ccRCC patients, for example, INK4, SFRP1, and SFRP2 were reviewed by Baldewijns et al. in 2008 (4). Recently, to our knowledge, only two more reports have been published. RASSF1A, and VHL (detected in serum) as well as KILLIN, and LINE-1 (detected in peripheral blood) have been proposed as predictive biomarkers (68-70). Their association with ccRCC is suggested by significantly higher levels of promoter hypermethylation in ccRCC patients than in patients with benign tumors and healthy controls, respectively. High throughput screening strategies that revealed many new ccRCC biomarker candidates, give hope that in the near future exploration of fluid based epigenetic biomarkers will be intensified.

\section{Epigenetic therapies}

Studies that highlighted importance of epigenetic modifications in the pathogenesis of ccRCC provided new potential objects for therapeutic intervention. Cancer cells, including ccRCC, are generally characterized by the overexpression of HDACs leading to decreased histone acetylation and consequently silencing of genes involved in the regulation of key cancer pathways $(71$, 72). Several studies proved the efficacy of some HDAC inhibitors in reducing tumor growth in cancer patients in phase I and II clinical trials (72-74). Currently, HDACs are intensively explored as targets of ccRCC therapy $(67,75)$. Monotherapies such as, with panobinostat, did not bring satisfactory results to date. A phase II study enrolled 20 patients with metastatic refractory ccRCC, previously treated with mTOR inhibitor(s). In the first evaluation, five patients showed stable disease and three patients experienced progression. Treatment was generally well tolerated but the median progression-free survival was limited to 17 months. Hence, panobinostat is recommended only in combination with other anticancer drugs (76). Also depsipeptide, tested in 29 patients with metastatic RCC (ccRCC $n=25$ ) in a phase II study, did not show satisfactory results as a monotherapy. The overall treatment response rate was $7 \%$, in addition severe side effects like fatigue, nausea, vomiting, anemia were observed (77).

Combined treatment approaches with HDAC inhibitors seem to be more effective than monotherapy. In models of RCC, the HDAC inhibitor vorinostat improved the anticancer activity of temsirolimus (78). Reduced cell viability, clonogenic survival and increased cell death was observed in RCC cell lines (86-O, A498, 769-P, Caki-1, Caki-2, SW839, ACHN, G401 and SK-NEP$1)$ in response to combined treatment. In xenografts of RCC cell lines (786-O and Caki-1), vorinostat inhibited tumor cell proliferation, induced apoptosis and impaired angiogenesis, through a decrease in HIF-2a expression and vessel density. In vitro and in vivo studies have also shown that a combination of retinoic acid and HDAC inhibitor trichostatin $A$ is more efficient than each drug alone (79). The combined therapy enhanced the retinoic acid pathway signaling, leading to a reduction of proliferation of human $\mathrm{RCC}$ cells lines (SK-RC-39 and SK-RC-45), inhibition of tumor model growth (SK-RC39) and increased apoptosis. In combination with retinoids, also MS-275, a benzamine derivative HDAC inhibitor, showed a better inhibitory effect on tumor growth in vivo. This effect persisted after treatment withdrawal, and after continuous treatment in animals RCC1.18 tumor progression was not observed (80). Interestingly, an induction of retinoic acid receptor beta was observed during treatment, suggesting HDAC inhibitors might revert retinoid resistance.

There are also attempts to develop drugs selectively targeting other enzymes involved in epigenetic modulation, especially histone methyltransferases or histone demethylases. There are a few methyltransferase inhibitors showing promising results in cancer models (75, 81). In ccRCC, the S-adenosylhomocysteine hydrolase inhibitor, 3-deazaneplanocin A (DZNep), depletes cellular levels of the enhancer of zeste homologue 2 (EZH2). $\mathrm{EZH} 2$ is a catalytic subunit of the polycomb repressive complex 2 (PRC2), a histone methyltransferase that catalyzes tri-methylation of lysine 27 on histone 3 
(82). DZNep reduces H3K27 trimethylation levels, additionally, RCC cells exposed to DZNep showed a significant decrease of cell migration and invasion in vitro, as well as inhibition of tumor growth, and prolonged survival in the in vivo mice model.

In a recent report published by Adelaiye et al., resistance to sunitinib was studied in mice bearing two different patient-derived ccRCC xenografts (83). Increasing the drug dose led to partial overcome of initial sunitinib-induced resistance, suggesting its association with epigenetic changes such as overexpression of the methyltransferase EZH2 and modulation of histone marks. Moreover, specific EZH2 inhibition resulted in increased in vitro anti-tumor effect of sunitinib. These promising results indicate that high throughput screening strategies could be used to identify further drugcandidates.

\section{Perspectives}

Availability of high-throughput methods have facilitated investigation of epigenetic modifications in general. The Roadmap Epigenomics Program recently published mapped epigenomes of 111 types of primary human healthy cells and tissues, providing valuable reference epigenome maps (84), moreover many epigenome-wide association studies (EWASs) initiated in various diseases are currently intensively conducted (85). Epigenetic studies have also widely broadened our understanding of the biology of ccRCC, providing evidence of various DNA mutation and methylation events, chromatin alterations and changes of DNA accessibility, and altogether suggesting that epigenetic alterations are connected to ccRCC pathogenesis/progression and require further detailed examination. A number of new large-scale projects seeking RCC biomarkers are currently ongoing, for example, CAGEKID, "Biomarker pipeline" (NIH), EuroTARGET or the PREDICT consortium $(66,86-89)$. These studies are expected to identify and characterize novel candidate biomarkers for ccRCC detection, staging and monitoring.

\section{References}

1. Mathew A, Devesa SS, Fraumeni JF, Jr., Chow WH. Global increases in kidney cancer incidence, 1973-1992. Eur J Cancer Prev 2002; 11(2):171-178.

Doi:

http://dx.doi.org/10.1097/00008469200204000-00010

2. Sun $M$ et al. Age-adjusted incidence, mortality, and survival rates of stage-specific renal cell carcinoma in North America: a trend analysis. Eur Urol 2011; 59(1):135-141.

Doi:

http:/.dx.doi.org/10.1016/j.eururo.2010.10.02 9

3. Ferlay J SI, Ervik M, Dikshit R, Eser S, Mathers C, Rebelo M, Parkin DM, Forman D, Bray, F. (2012 v1.0) GLOBOCAN Cancer Incidence and Mortality Worldwide: IARC CancerBase No 11. Internet

4. Baldewijns MM, van Vlodrop IJ, Schouten LJ, Soetekouw PM, de Bruine AP, van Engeland M. Genetics and epigenetics of renal cell cancer. Biochim Biophys Acta 2008; 1785(2):133-155.

Doi:

http://dx.doi.org/10.1016/j.bbcan.2007.12.002

5. Brugarolas J. Renal-cell carcinoma-molecular pathways and therapies. $\mathrm{N}$ Engl $\mathrm{J}$ Med 2007; 356(2):185-187.

Doi:

http://dx.doi.org/ 10.1056/NEJMe068263

6. Motzer RJ. New perspectives on the treatment of metastatic renal cell carcinoma: an introduction and historical overview. Oncologist 2011; 16 Suppl 2:1-3.

Doi:

http://dx.doi.org/10.1634/theoncologist.2011$\mathrm{S} 2-01$

7. Wood CG. Multimodal approaches in the management of locally advanced and metastatic renal cell carcinoma: combining surgery and systemic therapies to improve patient outcome. Clin Cancer Res 2007; 13(2 Pt 2):697s-702s. Doi:

http://dx.doi.org/10.1158/1078-0432.CCR-062109

8. Weiss RH, Lin PY. Kidney cancer: identification of novel targets for therapy. Kidney Int 2006; 69(2):224-232.

Doi:

http://dx.doi.org/10.1038/sj.ki.5000065

\section{Conflict of interest}

None 
9. Gossage L, Eisen T, Maher ER. VHL, the story of a tumour suppressor gene. Nat Rev Cancer 2015; 15(1):55-64.

Doi:

http:/ /dx.doi.org/ 10.1038/nrc3844

10. Varela I et al. Exome sequencing identifies frequent mutation of the SWI/SNF complex gene PBRM1 in renal carcinoma. Nature 2011; 469(7331):539-542.

Doi:

http://dx.doi.org/10.1038/nature09639

11. Dalgliesh GL et al. Systematic sequencing of renal carcinoma reveals inactivation of histone modifying genes. Nature 2010; 463(7279):360363.

Doi:

http://dx.doi.org/10.1038/nature08672

12. Guo $\mathrm{G}$ et al. Frequent mutations of genes encoding ubiquitin-mediated proteolysis pathway components in clear cell renal cell carcinoma. Nat Genet 2012; 44(1):17-19.

Doi:

http://dx.doi.org/10.1038/ng.1014

13. Herman JG et al. Silencing of the VHL tumor-suppressor gene by DNA methylation in renal carcinoma. Proc Natl Acad Sci U S A 1994; 91(21):9700-9704.

Doi:

http:/ /dx.doi.org/ 10.1073/pnas.91.21.9700

14. Kouzarides T. Chromatin modifications and their function. Cell 2007; 128(4):693-705.

Doi:

http://dx.doi.org/10.1016/j.cell.2007.02.005

15. Sharma S, Kelly TK, Jones PA. Epigenetics in cancer. Carcinogenesis 2010; 31(1):27-36. Doi:

http:/ /dx.doi.org/10.1093/carcin/bgp220

16. Comprehensive molecular characterization of clear cell renal cell carcinoma. Nature 2013; 499(7456):43-49.

Doi:

http://dx.doi.org/10.1038/nature12222

17. Ricketts CJ, Hill VK, Linehan WM. Tumorspecific hypermethylation of epigenetic biomarkers, including SFRP1, predicts for poorer survival in patients from the TCGA Kidney Renal Clear Cell Carcinoma (KIRC) project. PLoS One 2014; 9(1):e85621.

Doi:

http:/ / dx.doi.org/10.1371/journal.pone.00856 21

18. Rydzanicz M, Wrzesinski T, Bluyssen HA, Wesoly J. Genomics and epigenomics of clear cell renal cell carcinoma: recent developments and potential applications. Cancer Lett 2013; 341(2):111-126.

Doi:

http://dx.doi.org/10.1016/j.canlet.2013.08.006

19. Bird A. DNA methylation patterns and epigenetic memory. Genes Dev 2002; 16(1):6-21. Doi:

http://dx.doi.org/10.1101/gad.947102

20. Bock C. Analysing and interpreting DNA methylation data. Nat Rev Genet 2012; 13(10):705-719.

Doi:

http: / /dx.doi.org/ 10.1038/nrg3273

21. Jones PA. Functions of DNA methylation: islands, start sites, gene bodies and beyond. Nat Rev Genet 2012; 13(7):484-492.

Doi:

http://dx.doi.org/10.1038/nrg3230

22. Okano M, Bell DW, Haber DA, Li E. DNA methyltransferases Dnmt3a and Dnmt3b are essential for de novo methylation and mammalian development. Cell 1999; 99(3):247257.

Doi:

http://dx.doi.org/10.1016/S0092-

8674(00)81656-6

23. Kim GD, Ni J, Kelesoglu N, Roberts RJ, Pradhan S. Co-operation and communication between the human maintenance and de novo DNA (cytosine-5) methyltransferases. EMBO J 2002; 21(15):4183-4195.

Doi:

http:/ / dx.doi.org/10.1093/emboj/cdf401

24. Wang Y, Leung FC. An evaluation of new criteria for $\mathrm{CpG}$ islands in the human genome as gene markers. Bioinformatics 2004; 20(7):1170-1177.

Doi:

http:/ / dx.doi.org/10.1093/bioinformatics/bth0 59

25. Tsai HC, Baylin SB. Cancer epigenetics: linking basic biology to clinical medicine. Cell Res 2011; 21(3):502-517.

Doi:

http://dx.doi.org/10.1038/cr.2011.24

26. Clifford SC, Prowse AH, Affara NA, Buys CH, Maher ER. Inactivation of the von Hippel-Lindau (VHL) tumour suppressor gene and allelic losses at chromosome arm $3 p$ in primary renal cell carcinoma: evidence for a VHL-independent pathway in clear cell renal tumourigenesis. Genes Chromosomes Cancer 1998; 22(3):200209.

Doi: 
http:/ /dx.doi.org/ 10.1002 / (SICI) 10982264(199807)22:3<200::AID-GCC5>3.0.CO;2-\#

27. Nickerson ML et al. Improved identification of von Hippel-Lindau gene alterations in clear cell renal tumors. Clin Cancer Res 2008; 14(15):4726-4734.

Doi:

http:/ /dx.doi.org/ 10.1158/1078-0432.CCR-074921

28. Morris MR, Maher ER. Epigenetics of renal cell carcinoma: the path towards new diagnostics and therapeutics. Genome Med 2010; 2(9):59.

Doi:

http:/ /dx.doi.org/10.1186/gm180

29. Morris MR, Ricketts C, Gentle D, Abdulrahman M, Clarke N, Brown M, Kishida T, Yao M, Latif F, Maher ER. Identification of candidate tumour suppressor genes frequently methylated in renal cell carcinoma. Oncogene 2010; 29(14):2104-2117.

Doi:

http://dx.doi.org/10.1038/onc.2009.493

30. Morris MR et al. Genome-wide methylation analysis identifies epigenetically inactivated candidate tumour suppressor genes in renal cell carcinoma. Oncogene 2011; 30(12):1390-1401. Doi:

http://dx.doi.org/10.1038/onc.2010.525

31. McRonald FE et al. CpG methylation profiling in VHL related and VHL unrelated renal cell carcinoma. Mol Cancer 2009; 8:31. Doi:

http://dx.doi.org/10.1186/1476-4598-8-31

32. Ricketts CJ, Morris MR, Gentle D, Brown M, Wake N, Woodward ER, Clarke N, Latif F, Maher ER. Genome-wide $\mathrm{CpG}$ island methylation analysis implicates novel genes in the pathogenesis of renal cell carcinoma. Epigenetics 2012; 7(3):278-290.

Doi:

http:/ / dx.doi.org/ 10.4161/epi.7.3.19103

33. Dmitriev AA et al. Epigenetic alterations of chromosome 3 revealed by NotI-microarrays in clear cell renal cell carcinoma. Biomed Res Int 2014; 2014:735292.

Doi:

http://dx.doi.org/10.1155/2014/735292

34. Jiang C, Pugh BF. Nucleosome positioning and gene regulation: advances through genomics. Nat Rev Genet 2009; 10(3):161-172. Doi:

http:/ /dx.doi.org/ 10.1038/nrg2522
35. Hohmann AF, Vakoc CR. A rationale to target the SWI/SNF complex for cancer therapy. Trends Genet 2014; 30(8):356-363.

Doi:

http://dx.doi.org/10.1016/j.tig.2014.05.001

36. Reisman D, Glaros S, Thompson EA. The SWI/SNF complex and cancer. Oncogene 2009; 28(14):1653-1668.

Doi:

http:/ / dx.doi.org/10.1038/onc.2009.4

37. Pena-Llopis S et al. BAP1 loss defines a new class of renal cell carcinoma. Nat Genet 2012; 44(7):751-759.

Doi:

http://dx.doi.org/10.1038/ng.2323

38. Pawlowski R, Muhl SM, Sulser T, Krek W, Moch H, Schraml P. Loss of PBRM1 expression is associated with renal cell carcinoma progression. Int J Cancer 2013; 132(2):E11-17. Doi:

http://dx.doi.org/10.1002/ijc.27822

39. Xia W, Nagase S, Montia AG, Kalachikov SM, Keniry M, Su T, Memeo L, Hibshoosh H, Parsons R. BAF180 is a critical regulator of p2 1 induction and a tumor suppressor mutated in breast cancer. Cancer Res 2008; 68(6):16671674.

Doi:

http:/ /dx.doi.org/ 10.1158/0008-5472.CAN-075276

40. Kapur P, Pena-Llopis S, Christie A, Zhrebker L, Pavia-Jimenez A, Rathmell WK, Xie XJ, Brugarolas J. Effects on survival of BAP1 and PBRM1 mutations in sporadic clear-cell renalcell carcinoma: a retrospective analysis with independent validation. Lancet Oncol 2013; 14(2):159-167.

Doi:

http: / / dx.doi.org/10.1016/S1470-

2045(12)70584-3

41. Lichner Z, Scorilas A, White NM, Girgis AH, Rotstein L, Wiegand $\mathrm{KC}$, Latif A, Chow C, Huntsman D, Yousef GM. The chromatin remodeling gene ARID1A is a new prognostic marker in clear cell renal cell carcinoma. Am J Pathol 2013; 182(4):1163-1170.

Doi:

http://dx.doi.org/10.1016/j.ajpath.2013.01.00 7

42. Girgis $\mathrm{AH}$ et al. Multilevel whole-genome analysis reveals candidate biomarkers in clear cell renal cell carcinoma. Cancer Res 2012; 72(20):5273-5284.

Doi:

http://dx.doi.org/10.1158/0008-5472.CAN-120656 
43. Wu JN, Roberts CW. ARID1A mutations in cancer: another epigenetic tumor suppressor? Cancer Discov 2013; 3(1):35-43.

Doi:

http: / /dx.doi.org/ 10.1158/2159-8290.CD-120361

44. Kelly TK, De Carvalho DD, Jones PA. Epigenetic modifications as therapeutic targets. Nat Biotechnol 2010; 28(10):1069-1078.

Doi:

http://dx.doi.org/10.1038/nbt.1678

45. Ruthenburg AJ, Li H, Patel DJ, Allis CD. Multivalent engagement of chromatin modifications by linked binding modules. Nat Rev Mol Cell Biol 2007; 8(12):983-994.

Doi:

http:/ /dx.doi.org/10.1038/nrm2298

46. Haberland M, Montgomery RL, Olson EN. The many roles of histone deacetylases in development and physiology: implications for disease and therapy. Nat Rev Genet 2009; 10(1):32-42.

Doi:

http://dx.doi.org/10.1038/nrg2485

47. Duns G, van den Berg E, van Duivenbode I, Osinga J, Hollema H, Hofstra RM, Kok K. Histone methyltransferase gene SETD2 is a novel tumor suppressor gene in clear cell renal cell carcinoma. Cancer Res 2010; 70(11):42874291.

Doi:

http:/ / dx.doi.org/ 10.1158/0008-5472.CAN-100120

48. Pena-Llopis S, Christie A, Xie XJ, Brugarolas J. Cooperation and antagonism among cancer genes: the renal cancer paradigm. Cancer Res 2013; 73(14):4173-4179.

Doi:

http:/ / dx.doi.org/ 10.1158/0008-5472.CAN-130360

49. Gerlinger $M$ et al. Intratumor heterogeneity and branched evolution revealed by multiregion sequencing. N Engl J Med 2012; 366(10):883892.

Doi:

http:/ /dx.doi.org/ 10.1056/NEJMoa1113205

50. Li F, Mao G, Tong D, Huang J, Gu L, Yang $\mathrm{W}$, Li GM. The histone mark H3K36me3 regulates human DNA mismatch repair through its interaction with MutSalpha. Cell 2013; 153(3):590-600.

Doi:

http://dx.doi.org/10.1016/j.cell.2013.03.025
51. Alexandrov LB et al. Signatures of mutational processes in human cancer. Nature 2013; 500(7463):415-421.

Doi:

http://dx.doi.org/10.1038/nature12477

52. Kanu $\mathrm{N}$ et al. SETD2 loss-of-function promotes renal cancer branched evolution through replication stress and impaired DNA repair. Oncogene 2015.

Doi:

http://dx.doi.org/10.1038/onc.2015.24

53. Carvalho S, Vitor AC, Sridhara SC, Martins FB, Raposo AC, Desterro JM, Ferreira J, de Almeida SF. SETD2 is required for DNA doublestrand break repair and activation of the p53mediated checkpoint. Elife 2014; 3:e02482.

Doi:

http:/ /dx.doi.org/ 10.7554/eLife.02482

54. van Haaften G et al. Somatic mutations of the histone H3K27 demethylase gene UTX in human cancer. Nat Genet 2009; 41(5):521-523. Doi:

http:/ /dx.doi.org/10.1038/ng.349

55. Niu X, Zhang T, Liao L, Zhou L, Lindner DJ, Zhou M, Rini B, Yan Q, Yang H. The von HippelLindau tumor suppressor protein regulates gene expression and tumor growth through histone demethylase JARID1C. Oncogene 2012; 31(6):776-786.

Doi:

http:/ /dx.doi.org/10.1038/onc.2011.266

56. Sato Y et al. Integrated molecular analysis of clear-cell renal cell carcinoma. Nat Genet 2013; 45(8):860-867.

Doi:

http:/ / dx.doi.org/ 10.1038/ng.2699

57. Cao J, Yan Q. Histone ubiquitination and deubiquitination in transcription, DNA damage response, and cancer. Front Oncol 2012; 2:26.

Doi:

http:/ /dx.doi.org/10.3389/fonc.2012.00026

58. Wang SS et al. Bap1 is essential for kidney function and cooperates with Vhl in renal tumorigenesis. Proc Natl Acad Sci U S A 2014; 111(46):16538-16543.

Doi:

http://dx.doi.org/ 10.1073/pnas. 1414789111

59. Simon JM, Giresi PG, Davis IJ, Lieb JD. Using formaldehyde-assisted isolation of regulatory elements (FAIRE) to isolate active regulatory DNA. Nat Protoc 2012; 7(2):256-267. Doi:

http: / / dx.doi.org/ 10.1038/nprot.2011.444 
60. Buck MJ, Raaijmakers LM, Ramakrishnan S, Wang D, Valiyaparambil S, Liu S, Nowak NJ, Pili R. Alterations in chromatin accessibility and DNA methylation in clear cell renal cell carcinoma. Oncogene 2014; 33(41):4961-4965. Doi:

http://dx.doi.org/10.1038/onc.2013.455

61. Simon JM et al. Variation in chromatin accessibility in human kidney cancer links H3K36 methyltransferase loss with widespread RNA processing defects. Genome Res 2014; 24(2):241-250.

Doi:

http:/ /dx.doi.org/10.1101/gr.158253.113

62. Hakimi AA et al. Clinical and pathologic impact of select chromatin-modulating tumor suppressors in clear cell renal cell carcinoma. Eur Urol 2013; 63(5):848-854.

Doi:

http://dx.doi.org/10.1016/j.eururo.2012.09.00 5

63. Hakimi AA et al. Adverse outcomes in clear cell renal cell carcinoma with mutations of $3 \mathrm{p} 21$ epigenetic regulators BAP1 and SETD2: a report by MSKCC and the KIRC TCGA research network. Clin Cancer Res 2013; 19(12):32593267.

Doi:

http://dx.doi.org/10.1158/1078-0432.CCR-123886

64. Arai E, Chiku S, Mori T, Gotoh M, Nakagawa T, Fujimoto H, Kanai Y. Single-CpGresolution methylome analysis identifies clinicopathologically aggressive $\mathrm{CpG}$ island methylator phenotype clear cell renal cell carcinomas. Carcinogenesis 2012; 33(8):14871493.

Doi:

http://dx.doi.org/ 10.1093/carcin/bgs 177

65. Tian $\mathrm{Y}$, Arai E, Gotoh M, Komiyama M, Fujimoto H, Kanai Y. Prognostication of patients with clear cell renal cell carcinomas based on quantification of DNA methylation levels of $\mathrm{CpG}$ island methylator phenotype marker genes. BMC Cancer 2014; 14:772.

Doi:

http:/ / dx.doi.org/ 10.1186/1471-2407-14-772

66. Vasudev NS, Selby PJ, Banks RE. Renal cancer biomarkers: the promise of personalized care. BMC Med 2012; 10:112.

Doi:

http:/ /dx.doi.org/10.1186/1741-7015-10-112

67. Vieira-Coimbra M, Henrique R, Jeronimo C. New insights on chromatin modifiers and histone post-translational modifications in renal cell tumours. Eur J Clin Invest 2015; 45 Suppl $1: 16-24$.

Doi:

http://dx.doi.org/10.1111/eci.12360

68. de Martino M, Klatte T, Haitel A, Marberger M. Serum cell-free DNA in renal cell carcinoma: a diagnostic and prognostic marker. Cancer 2012; 118(1):82-90.

Doi:

http:/ /dx.doi.org/10.1002/cncr.26254

69. Bennett KL, Campbell R, Ganapathi S, Zhou M, Rini B, Ganapathi R, Neumann HP, Eng C. Germline and somatic DNA methylation and epigenetic regulation of KILLIN in renal cell carcinoma. Genes Chromosomes Cancer 2011; 50(8):654-661.

Doi:

http:/ /dx.doi.org/ 10.1002/gcc.20887

70. Liao LM et al. LINE-1 methylation levels in leukocyte DNA and risk of renal cell cancer. PLoS One 2011; 6(11):e27361.

Doi:

http://dx.doi.org/10.1371/journal.pone.00273 61

71. Fritzsche FR et al. Class I histone deacetylases 1, 2 and 3 are highly expressed in renal cell cancer. BMC Cancer 2008; 8:381.

Doi:

http:/ /dx.doi.org/ 10.1186/1471-2407-8-381

72. Minardi D, Lucarini G, Filosa A, Milanese G, Zizzi A, Di Primio R, Montironi R, Muzzonigro G. Prognostic role of global DNA-methylation and histone acetylation in pT1a clear cell renal carcinoma in partial nephrectomy specimens. J Cell Mol Med 2009; 13(8B):2115-2121.

Doi:

http://dx.doi.org/10.1111/j.1582-

4934.2008.00482.x

73. Jones J, Juengel E, Mickuckyte A, Hudak L, Wedel S, Jonas D, Blaheta RA. The histone deacetylase inhibitor valproic acid alters growth properties of renal cell carcinoma in vitro and in vivo. J Cell Mol Med 2009; 13(8B):2376-2385.

Doi:

http:/ /dx.doi.org/10.1111/j.1582-

4934.2008.00436.x

74. Siu LL et al. Phase I study of MGCD0103 given as a three-times-per-week oral dose in patients with advanced solid tumors. J Clin Oncol 2008; 26(12):1940-1947.

Doi:

http:/ /dx.doi.org/10.1200/JCO.2007.14.5730

75. Larkin J, Goh XY, Vetter M, Pickering L, Swanton C. Epigenetic regulation in RCC: 
opportunities for therapeutic intervention? Nat Rev Urol 2012; 9(3):147-155.

Doi:

http:/ /dx.doi.org/ 10.1038/nrurol.2011.236

76. Hainsworth JD, Infante JR, Spigel DR, Arrowsmith ER, Boccia RV, Burris HA. A phase II trial of panobinostat, a histone deacetylase inhibitor, in the treatment of patients with refractory metastatic renal cell carcinoma. Cancer Invest 2011; 29(7):451-455.

Doi:

http://dx.doi.org/10.3109/07357907.2011.590 568

77. Stadler WM, Margolin K, Ferber S, McCulloch W, Thompson JA. A phase II study of depsipeptide in refractory metastatic renal cell cancer. Clin Genitourin Cancer 2006; 5(1):5760.

Doi:

http://dx.doi.org/10.3816/CGC.2006.n.018

78. Mahalingam D et al. Vorinostat enhances the activity of temsirolimus in renal cell carcinoma through suppression of survivin levels. Clin Cancer Res 2010; 16(1):141-153.

Doi:

http://dx.doi.org/ 10.1158/1078-0432.CCR-091385

79. Touma SE, Goldberg JS, Moench P, Guo X, Tickoo SK, Gudas LJ, Nanus DM. Retinoic acid and the histone deacetylase inhibitor trichostatin a inhibit the proliferation of human renal cell carcinoma in a xenograft tumor model. Clin Cancer Res 2005; 11(9):3558-3566.

Doi:

http:/ /dx.doi.org/10.1158/1078-0432.CCR-041155

80. Wang XF, Qian DZ, Ren M, Kato Y, Wei Y, Zhang L, Fansler Z, Clark D, Nakanishi O, Pili R. Epigenetic modulation of retinoic acid receptor beta2 by the histone deacetylase inhibitor MS-275 in human renal cell carcinoma. Clin Cancer Res 2005; 11(9):35353542.

Doi:

http:/ / dx.doi.org/ 10.1158/1078-0432.CCR-041092

81. Spannhoff A, Sippl W, Jung M. Cancer treatment of the future: inhibitors of histone methyltransferases. Int $\mathrm{J}$ Biochem Cell Biol 2009; 41(1):4-11.

Doi:

http://dx.doi.org/10.1016/j.biocel.2008.07.024

82. Liu L, Xu Z, Zhong L, Wang $\mathrm{H}$, Jiang S, Long $\mathrm{Q}$, Xu J, Guo J. EZH2 promotes tumor cell migration and invasion via epigenetic repression of E-cadherin in renal cell carcinoma. BJU Int 2014.

Doi:

http://dx.doi.org/10.1111/bju.12702

83. Adelaiye $\mathrm{R}$ et al. Sunitinib dose escalation overcomes transient resistance in clear cell renal cell carcinoma and is associated with epigenetic modifications. Mol Cancer Ther 2015; 14(2):513-522.

Doi:

http://dx.doi.org/10.1158/1535-7163.MCT-140208

84. Kundaje A et al. Integrative analysis of 111 reference human epigenomes. Nature 2015; 518(7539):317-330.

Doi:

http://dx.doi.org/10.1038/nature14248

85. Paul DS, Beck S. Advances in epigenomewide association studies for common diseases. Trends Mol Med 2014; 20(10):541-543.

Doi:

http:/ /dx.doi.org/10.1016/j.molmed.2014.07.0 02

86. CAGEKID.

http://www.cng.fr/cagekid/index.html/

87. Biomarker pipeline.

http://www.biomarkerpipeline.org/nihr/

88. EuroTARGET.

http:/ / www.eurotargetproject.eu/

89. PREDICT consortium.

http:/ / www.predictconsortium.eu/

90. Hirata $\mathrm{H}$ et al. Wnt antagonist DKK1 acts as a tumor suppressor gene that induces apoptosis and inhibits proliferation in human renal cell carcinoma. Int J Cancer 2011; 128(8):17931803.

Doi:

http:/ /dx.doi.org/10.1002/ijc. 25507

91. Hirata $\mathrm{H}$ et al. Wnt antagonist gene DKK2 is epigenetically silenced and inhibits renal cancer progression through apoptotic and cell cycle pathways. Clin Cancer Res 2009; 15(18):56785687.

Doi:

http:/ /dx.doi.org/ 10.1158/1078-0432.CCR-090558

92. Urakami $\mathrm{S}$ et al. Wnt antagonist family genes as biomarkers for diagnosis, staging, and prognosis of renal cell carcinoma using tumor and serum DNA. Clin Cancer Res 2006; 12(23):6989-6997.

Doi: 
http: / / dx.doi.org/ 10.1158/1078-0432.CCR-061194

93. Christoph F, Weikert S, Kempkensteffen C, Krause H, Schostak M, Kollermann J, Miller K, Schrader M. Promoter hypermethylation profile of kidney cancer with new proapoptotic p53 target genes and clinical implications. Clin Cancer Res 2006; 12(17):5040-5046.

Doi:

http: / / dx.doi.org/ 10.1158/1078-0432.CCR-060144

94. Ahmad ST, Arjumand W, Seth A, Saini AK, Sultana S. Methylation of the APAF-1 and DAPK-1 promoter region correlates with progression of renal cell carcinoma in North Indian population. Tumour Biol 2012; 33(2):395-402.

Doi:

http:/ /dx.doi.org/ 10.1007/s13277-011-0235-9

95. Ibanez de Caceres I, Dulaimi E, Hoffman AM, Al-Saleem T, Uzzo RG, Cairns P. Identification of novel target genes by an epigenetic reactivation screen of renal cancer. Cancer Res 2006; 66(10):5021-5028.

Doi:

http:/ / dx.doi.org/ 10.1158/0008-5472.CAN-053365
96. Yoo KH, Park YK, Kim HS, Jung WW, Chang SG. Epigenetic inactivation of HOXA5 and MSH2 gene in clear cell renal cell carcinoma. Pathol Int 2010; 60(10):661-666.

Doi:

http:/ /dx.doi.org/10.1111/j.14401827.2010.02578.x

97. Zhang Q, Ying J, Li J, Fan Y, Poon FF, Ng KM, Tao Q, Jin J. Aberrant promoter methylation of DLEC1, a critical 3p22 tumor suppressor for renal cell carcinoma, is associated with more advanced tumor stage. J Urol 2010; 184(2):731-737.

Doi:

http:/ /dx.doi.org/10.1016/j.juro.2010.03.108

98. van Vlodrop IJ et al. Prognostic significance of Gremlin1 (GREM1) promoter $\mathrm{CpG}$ island hypermethylation in clear cell renal cell carcinoma. Am J Pathol 2010; 176(2):575-584. Doi:

http://dx.doi.org/ 10.2353/ajpath.2010.090442

99. Gossage L et al. Clinical and pathological impact of VHL, PBRM1, BAP1, SETD2, KDM6A, and JARID1c in clear cell renal cell carcinoma. Genes Chromosomes Cancer 2014; 53(1):38-51. Doi:

http://dx.doi.org/10.1002/gcc.22116 